Afore Tahir Harefa ${ }^{1}$

\section{AN ERROR ANALYSIS OF STUDENTS' RECOUNT TEXT ON SIMPLE PAST TENSE AT THE EIGHTH GRADE OF SMP NEGERI 4 GUNUNGSITOLI UTARA}

\begin{abstract}
:
The researcher conducted qualitative research used descriptive qualitative method. The researcher concluded that the types of error that were made by the students of the second year of SMP Negeri 4 Gunungsitoli Utara in their English writing from the highest frequency and percentage to the lowest are: error of misformation 257 (67\%), omission $60(16 \%)$, misordering $49(13 \%)$ and addition $20(5 \%)$. Meanwhile, the source of students error from the highest frequency and percentage to the lowest are interlingual $44(44 \%)$, intralingual $43(43 \%)$, context of learning $8(8 \%)$ and communication strategy $5(5 \%)$. In other words, most of the students were still influenced by their Indonesian language thinking. Besides, errors occurred because the students generalized the rule and applied it incompletely. Then, the errors occurred because of the the teacher explanation and the errors also occurred because of the students' learning techniques. Based on the result, the usage of simple past tense in writing recount text is difficult for the students. Then, the researcher also suggests the other researchers to do the research in the future because analysis research gives the evidence and support the next action.
\end{abstract}

Kata kunci: Error Analysis, Recount Text, Simple Past Tense

\title{
INTRODUCTION
}

Nowadays, English is the essential language that should be mastered by people as the tool for delivering the message to others and making an interaction with others. It is supported by the developments of using English as an international language. In other words, English has an effect for people to interact with others even in the other countries for business, political, economic, and other reasons. Based on the information, English included in curriculum learning of Indonesian as one of the expectation that should be mastered by the students. English is very important to learn, it needs to master four skills as the abilities to build communication in English, and they are listening, speaking, reading and writing.

Writing is a skill that is used to express idea in to written form. This skill is one of requirement that should be taugh to the students. It is supported by Turk and Kirkman

\footnotetext{
${ }^{1}$ Prodi Bahasa Inggris, IKIP Gunungsitoli

Alamat email: aforetahir_harefa@yahoo.com
} 
(1982:1), "Writing is a skill; like other skills, it can be learnt, and like most skills it is not inborn". For example, few people lack the basic equipment to learn to ride a bicycle (balance, strength, sight), but most become skilful cyclists only after much practice. According to Haris (2001: 306), a good writing must express good characteristic as follows: (1) Content: writing must convey the main idea or an attentive reader should be able to grasp the writer purpose. The substances of the writing; the idea expressed, (2) Form: writing should contain logical or associative connection and transition which clearly express the relationship of the ide described, (3) Grammar: writing should adhere to the rules of grammar related to the tenses with the sequence of time, the employment of grammatical forms and syntactic pattern, (4) Style: writing should engage its reader through original insight and precise. The choice of structures and lexical items to give a particular tone or flavor to the writing, (5) Mechanic: writing must use good spelling, punctuation, and tidy and clean writing.

Simple past tense is the tense that indicates the actions took place in the past or explain the accident that happened in the past time. It is supported by Alred at al (2012:547), state that the simple past tense indicates that an action took place in its entirety in the past. The past tense is usually formed by adding - $\mathrm{d}$ or -ed to the root form of the verb. Recount text is used to retell the story that had happened in the past time. According to Anderson in Siti Bayinah (2013:24), he states that recount is a piece of writing that retells past events usually in order in which they happened. Meanwhile, the purpose of a recount is to give the audience a description of what occurred and when it occurred. In other source tells that the purpose of a recount is to tell the readers what happened in the past through a sequence of events. In other words, recount text is writing text type which retells the past event chronologically. Every text has a schematic structure. According to Anderson in Siti Bayinah (2003:25), he states that recount has three schematic structures, they are, orientation, events, and reorientation. According to Anderson in Siti Bayinah (2003:16), there are some types of recount text, they are: eyewitness accounts, letters, conversations, newspaper Reports, television, interviews, and speech.

Ideally, in the syllabus of SMP Negeri 4 Gunungsitoli Utara, writing included as a skill that should be taught, particularly writing recount text. The Competence Standard is expressing the meaning of functional and short essay written text in descriptive and recount form to interact with others. Meanwhile, the Basic Competence in writing skill in recount text is expressing the meaning and rhetorical stages of short simple essay by using written language accurately, fluently and accepted to interact with others in descriptive and recount form.

Meanwhile, based on the preliminary study through observation and informal interview at the Eighth Grade of SMP Negeri 4 Gunungsitoli Utara that was done on December, 10th2018, many students made error in using simple past tense in Recount Text. The result of observation for the students of the eighth grade of SMP Negeri 4 Gunungsitoli Utara and informal interview from English teacher of the class showed that the students were not able to decide verb that used in simple past tense. It includes 
the use of past form of regular and irregular verb and the use of adverb of time to indicate that the event happened in the past.

Error in language use is the result of unsuccesfull of using language because of the failure of performance. It is supported by Coder in James (2013:79), states that errors are the result of some failures of performance. In other words, the performance in learning decides the successful of using language. James (1996: 106-110) proposes that errors can be classified into four types, they are: (1) Error of Omission, (2) Error of Addition, (3) Error of Misformation, and (4) Error of Misordering.

Error Analysis is the one way to analyze the students' error and the sources of the error particularly in the students recount text in using simple past tense. According to Mahmoodzadeh in Khresheh (2016:50), states that error analysis could be defined as a procedure used to identify, categorise, and explain the errors committed by foreign or second language learners. In addition, according to James (2013:1), "Error analysis is the process of determining the incidence, nature, causes and consequences of unsuccessful language". According to Corder in Ellis (1999: 48), there are some steps in error analysis research, they are: (1) Collecting of sample of learner language, (2) Identification of errors, (3) Description of errors, (4) Explanation of errors, dan (5) Evaluation of errors.

\section{RESEARCH METHOD}

In the research, the researcher used the inductive approach to do the research. Inductive approach proceeds from specific to general. The researcher conducted qualitative research used descriptive qualitative method because the researcher did the research in real time and directly do the research in the field. Qualitative research is a kind of the research which focus on describing, analyzing and interpreting the subject matter of research. According to Mcleod in Tavallae and Talib (2010:571), in qualitative research does not intend to test a hypothesis but this method has a deep tendency to describe, analyze, and interpret the constructive aspects of the social world.

In the Error Analysis research, the researcher conducted error analysis procedures which consists of collecting the data, identifying error, describing error, explaining errorand evaluating error. The first, collected the data, the researcher used test and interview as the source of data. The second, the researcher identified error, the researcher underlined every error made by the students of the test. The third, described error, the researcher classified error into table based on its types, they are omission, addition, misformation and misordering. The fourth, explained error, the researcher stated the sources of error based on identification and description of the error of the test and the result of interview. Finally, the researcher evaluated error, the researcher showed the errors include what the effect of error has and whoever is addressed.

The place of the research was SMP Negeri 4 Gunungsitoli Utara, Located in Hambawa village, Gunungsitoli Utara Subdistric, Gunungsitoli City. The data of the research was the result of the test and interview they are, the errors made by the students in their written test in using simple past tense and the transcription of the result of interview. The data source was the test of recount text by asking the students to arrange text by considering the use of simple past tense in the text. Furthermore, the 
interview for the students was related to their performance in using simple past tense in writing recount text. Based on the data, the researcher analyzed the types of error and the source of error made by the students. The Informant of this research was 31 students of the Eighth Grade of SMP Negeri 4 Gunungsitoli Utara.

\section{RESEARCH RESULT AND DISCUSSION}

The procedures of collecting the data have been mentioned clearly. The researcher has collected the sample of the students' language by the students' test result. Furthermore, the results of data collection could be seen as below:

\section{Result of the test}

The researcher found a lot of errors in using the simple past tense in students recount writing, and then the researcher made the classifying of the students ${ }^{\text {ee }}$ error on four types of error. It has been mentioned in the previous chapter, the writer only focused on the types of errors according to James (1996:106-110), error of omission, error of addition, error of misformation, and errors of misordering.

After identifying and describing error, the researcher counted the errors by using the table and calculated the number of each error. Next, the researcher processed the calculation of the result of the writing task by using the formula which has been mentioned in the table 1 .

Table 1. The Recapitulation of Frequency and Percentage of Students' Types of Error

\begin{tabular}{|c|c|c|c|}
\hline No & Types of error & Frequency & Percentage \\
\hline 1 & Omission & 60 & $16 \%$ \\
\hline 2 & Addition & 20 & $5 \%$ \\
\hline 3 & Misformation & 257 & $67 \%$ \\
\hline 4 & Misordering & 49 & $13 \%$ \\
\hline
\end{tabular}

Chart 1. The Percentage of Students' Types of Error

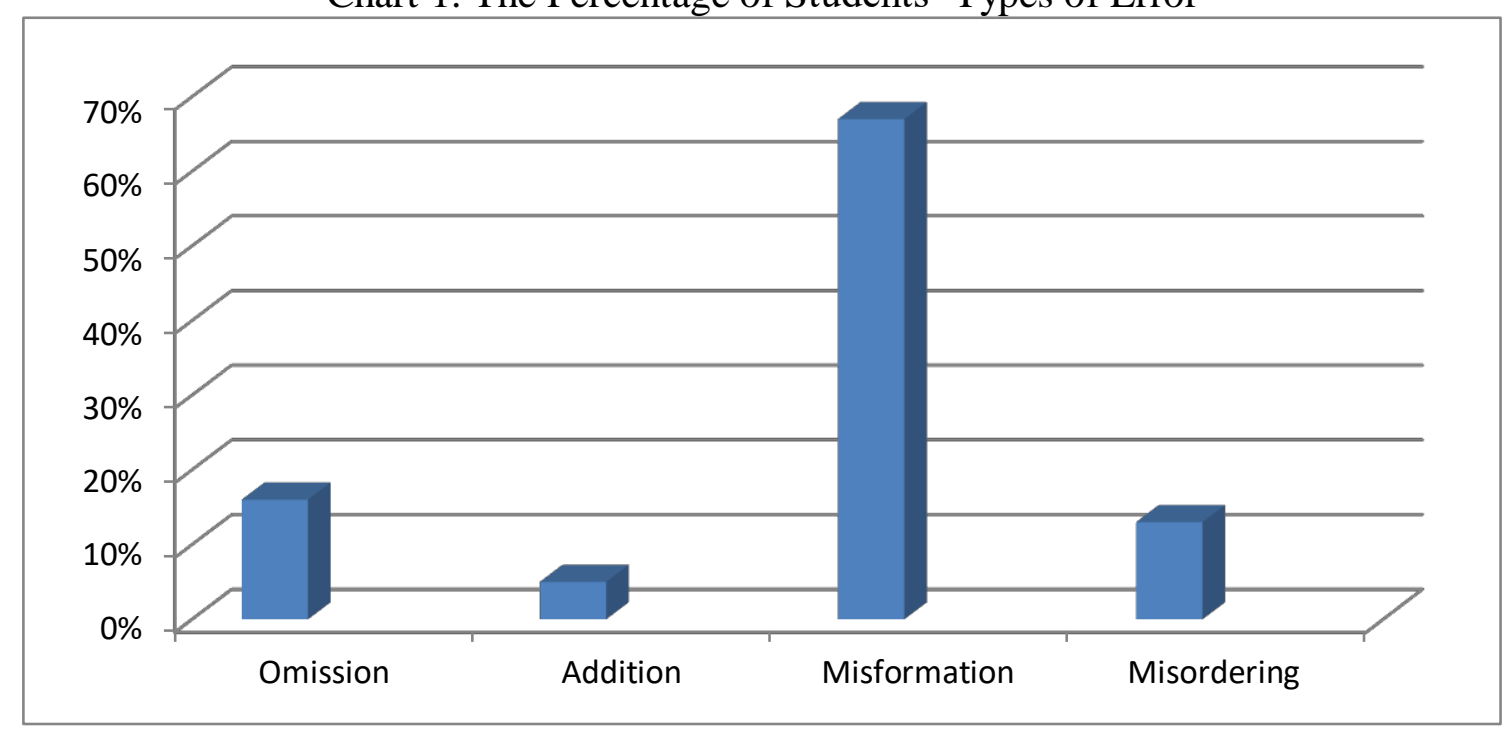

Clearly, the frequency of the types of error can be shown in graphic 2 below: 
Chart 2. Graphic The Frequency of Types of Error

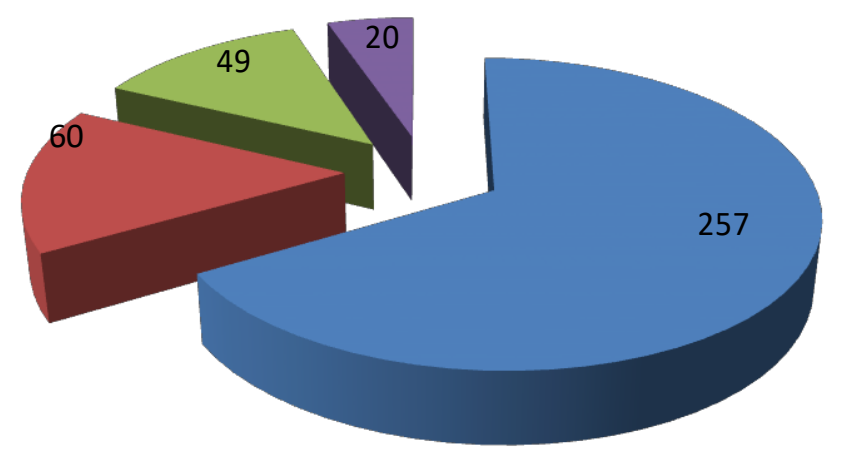

Misformation

Omission

Misordering

Addition

\section{Result of the Interview}

The researcher done the interview for the students after doing the test. The researcher composed the question based on the identification and description of the error. The researcher made the classifying of the students' error on four sources of error. It has been mentioned in the previous chapter, the writer only focused on the types of errors according to Brown (2000), intralingual, interlingual, context of learning, and communication strategy. After noting the students' reasons of why do they make error or source of error, the researcher counted the sources by using the table and calculated the number of each source. Next, the researcher processed the calculation of the result of the writing task by using percentage which is mentioned in the previous chapter.

Table 3. The Recapitulation of Frequency and Percentage of Students' Sources of Error

\begin{tabular}{|c|c|c|c|}
\hline No & Sources of Error & Frequency & Percentage \\
\hline 1 & Interlingual & 44 & $44 \%$ \\
\hline 2 & Intralingual & 43 & $43 \%$ \\
\hline 3 & Context of Learning & 8 & $8 \%$ \\
\hline 4 & Communication Strategy & 5 & $5 \%$ \\
\hline
\end{tabular}

Chart 3. The Percentage of Students' Sources of Error

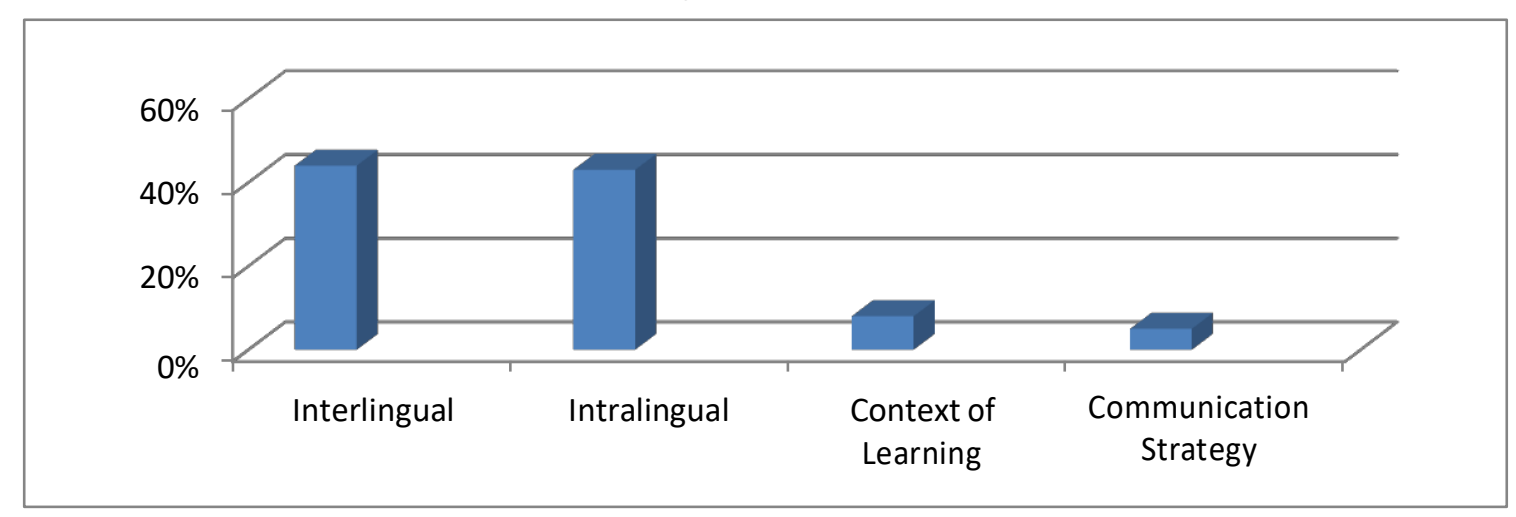


Chart 4. Graphic Frequency of Sources of Error

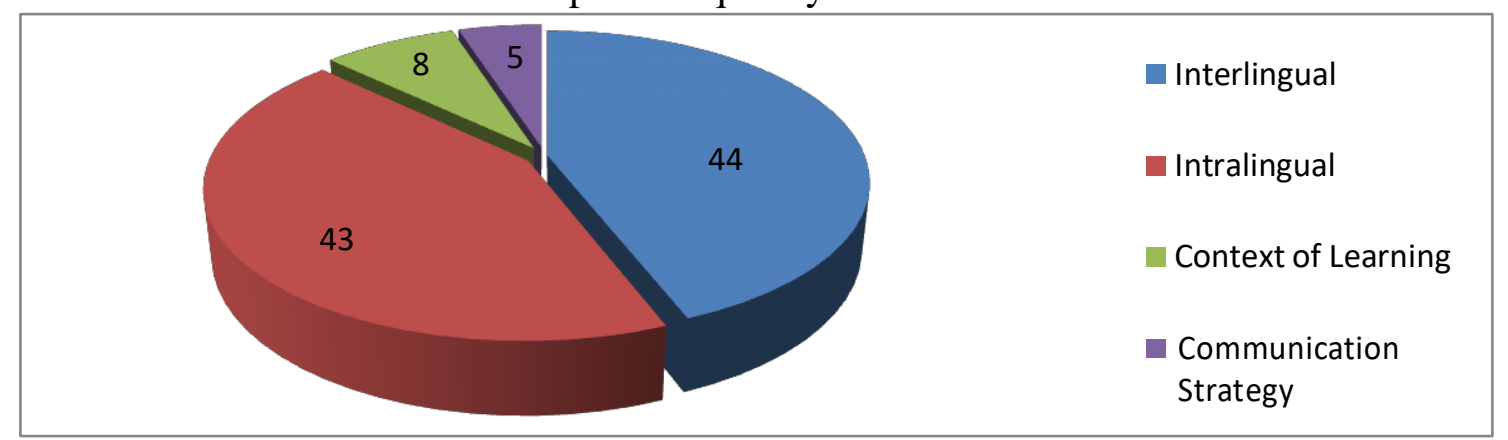

Based on the result of the interview above, interlingual, intralingual, context of learning and communication strategy are the sources of students' error in using simple past tense in writing recount text. The students made error in using simple past tense in writing recount text because they were affected by the four sources. The interlingual was the most frequently responded by the students with frequency 44 and percentage (44\%). Then, it is followed by intralingual source with the frequency 43, percentage (43\%), context of learning with the frequency 8 , percentage $(8 \%)$ and the lowest was communication strategy with the frequency 5 , and the percentage $(5 \%)$.

\section{The Description of Error}

Based on the recapitulation of the frequency and percentage of types of error, it shows that the types of error with percentage from the highest until the lowest are: misformation (67\%) which the frequency is 257 , omission $(16 \%)$ which the frequency is 60 , misordering $(13 \%)$ which the frequency is 49 and addition (5\%) which the frequency is 20 .

Based on the students' types' error, there are some examples of the students' error in using simple past tense in writing recount text, as follows:

- I help the teacher last week (categorized as misformation error)

- The teacher call me in the office (categorized as misformation error)

- The teacher say thanks and I answer thank you (categorized as misformation error)

- The teacher not .... Teach (categorized as omission error)

- I ... happy at the time (categorized as omission error)

- The teacher is punished me (categorized as addition error)

- I boughted the shoes (categorized as addition error)

- We together study (categorized as misordering error)

- We in the morning went (categorized as misordering error)

\section{The Explanation of Error}

Based on the recapitulation of frequency and percentage of sources of error, it shows that the sources of why do the students made error from the highest to the lowest percentage are: Interliangual (44\%) which the frequency is 44 , intralingual(43\%) which the frequency is 43 , communication strategy ( $8 \%$ ) which the frequency is 8 and context of learning $(5 \%)$ which the frequency is 5 . Therefore, it can be concluded that the 
source of why do the students make error in using simple past tense in writing recount text that has a little affection is the context of learning. The students made error because the teacher had not taught them more. Then, it is followed by communication strategy. This source also has little enough affection to the students. The students made error because their bad effort in learning. Then intralingual is the second highest frequency of students' source of making error, although it is slightly has the same frequency with the interlingual source. Meanwhile, the sources with the highest frequency is interlingual transfer. In other words, the students are affected by the rules of Indonesian language as their basic language.

\section{The Evaluation of Error}

Some errors can be considered more serious than others because they could hinder the message of the communication. In this research, the researcher considered that the students' error should be noticed by the students to evaluate their error. Based on the recapitulation of students' types of error, misformation is the highest frequency and percentage among the other types of error. This error should be evaluated well because the students always use the incorrect word in their sentence. However, the errors should be evaluated by presenting the corrections of the errors made by the students. There are some corrections of errors that have been done by the students:

- I help the teacher last week. The sentence should be (I helped the teacher last week)

- The teacher call me in the office. The sentence should be (The teacher called me in the office)

- We arrive in sibolga in the morning. The sentence should be (We arrived in sibolga in the morning)

- After we swim, we travel around the beach to look the people. The sentence should be (After we swam, we travelled around the beach to look the people)

- Before the exam, I study in home. The sentence should be (Before the exam, I studied in home)

Based on the examples, the errors of the students should be evaluated to make the students know their error.

\section{The Interpretation of the Error}

Based on the recapitulation of frequency and percentage of types of error, it can be interpreted that the addition error are the lowest frequency that the students made in using simple past tense. The students made little error in adding the unimportant items in their sentence. Then, it is followed by misordering error. The students also made little enough error in arranging the words. Omission error is the second highest frequency of students' types of error. The students were lost of the important items that should be presented in their sentence. Then, the most type of error that the student done in using simple past tense in writing recount text is misformation. The students made error in using the correct words in their sentences. Based on the recapitulation of frequency and percentage of sources of error, it can be interpreted that interlingual and intralingual as 
the major sources that affect the students in their writing particularly in using simple past tense in writing recount text. It is supported by the result which the most frequent sources of the errors are interlingual transfer and intralingual transfer with $44 \%$ for interlingual transfer, and $43 \%$ for intralingual transfer.

\section{The Research Finding Versus the Latest Related Research}

There were three previous researches related to Error Analysis. The first was done by Bayinah (2013), entitled "The Grammatical Error Analysis on Using Simple Past Tense in Writing Recount Text. This related research was in line with this research, which has the same focus of the research, they are : to know the students' types of error and sources of error. In addition, this related research has the same result with this research, which resulted miselection error was the highest frequency, although the researches are different in using the term miselection and misformation. In addition. interlingual sources as the sources of that errors. The second related research was done by Anwar (2014), entitled "An Error Analysis on the Use of Simple Past Tense in Students' Narrative Writing". This related research only focused on the students types of error, which resulted that misformation error was the highest frequency. The third related research was done by Millah (2016), entitled "An Error Analysis on the Use of Simple Past Tense in Students Recount Text Writing. This related research is in line with the research. The research resulted that misformation was the highest frequency and interlingual was also as the sources of the students' error.

\section{The Research Finding Versus Theory}

After getting the result of the research, the researcher compared it with the theories written by some experts. According to James (2013:1), "Error Analysis is the process of determining the incidence, nature, causes and consequences of unsuccessful language". The theory of Gass and Selinker (2008:103), states that there are two main error types within an error analysis framework: interlingual and intralingual. In addition, Corder in Ellis (1999:48), states that error has the significant in three ways:

- They provided the teacher with information about how much the learner has learnt

- They provided the researcher with evidence of how language was learnt

- They served as device by which the learner discovered the rules of the target language.

From the theories, the research finding of the research was in line with the all the theories above. Based on the theory of James, the research as the process of analyzing the students' error in using simple past tense in writing recount text. Furthermore, based on the theory of Gass and Selinker, the research proofed the theory that interlingual and interlingual are the major sources of the students in making error. In the research, interlingual and intralingual have the little interval which the range is only $1 \%$. Moreover, based on the theory of Corder in Ellis, the research is important. By identifying and describing the error, the teacher will know how much the learner has learnt and what should be done to face the error. 


\section{CONCLUSION}

The researcher concluded that the types of error that were made by the students of the second year of SMP Negeri 4 Gunungsitoli Utara in their English writing from the highest frequency and percentage to the lowest are: error of misformation 257 (67\%), omission $60(16 \%)$, misordering $49(13 \%)$ and addition $20(5 \%)$. Meanwhile, the source of students error from the highest frequency and percentage to the lowest are interlingual 44 (44\%), intralingual 43 (43\%), context of learning $8(8 \%)$ and communication strategy $5(5 \%)$. In other words, most of the students were still influenced by their Indonesian language thinking. Besides, errors occurred because the students generalized the rule and applied it incompletely. Then, the errors occurred because of the the teacher explanation and the errors also occurred because of the students' learning techniques. Based on the result, the usage of simple past tense in writing recount text is difficult for the students.

Regarding to those explanations, it can be concluded that error analysis is the best way to analyze the students' error. The analysis of error offers the improvement both of teacher and students in teaching learning of English. After knowing the students error, the teacher are able to decide the future action that can solve and evaluate the students' error and particularly in improving the students' ability in English. In other side, after knowing their error, the students will be aware of their error that need to be improved and evaluated.

\section{SUGGESTION}

Based on the result of analysis, the researcher intends to give some suggestions. The first, the teacher has to keep giving students writing tasks regularly. The teacher should emphasize the use of correct words in their writing such as the use of verb in simple past tense and other items to the students. The second, the teacher has to teach more about writing by explaining the use of English rules, tenses and everything related to the writing in English. In addition, the teacher has to make the students know the different of English and Indonesian language.

In addition, the researcher suggests that the school of SMP Negeri 4 Gunungsitoli Utara has to improve the teaching learning of English in the future particularly in making the students to master English by habitualizing the students to use English in every opportunity of learning English. Then, the researcher also suggests the other researchers to do the research in the future because analysis research gives the evidence and support the next action.

\section{DAFTAR PUSTAKA}

Alred. J, at all. 2012. Handbook of Technical Writing. Boston,New York

Anderson, J.2003. Handbook of Effective Writing. Oxford Uniiversity Press.

Anwar, Saipul. 2014. An Error Analysis on the Use of Simple Past Tense in Students' Narative Writing (A Case Study at First Grade Students of SMA Dua Mei Ciputat). 
Bayinah, Siti. (2013). The Grammatical Error Analysis on Using the Simple Past Tense in Writing Recount Text (A Case Study at the First Grade on MA Al - Khairiyah). Faculty of Tarbiya and English Education, Syarif Hidayatullah.

Brown, H. Douglas. (2000). Principle of language learning and teaching(4th ed). New York: Addison Wesley Logman

Corder, S. Pit. (1999). Error Analysis and Interlanguage. Oxford University Press.

Dakhi, O. "Aplikasi Pendeteksian Kerusakan File Akibat Virus Dengan Menggunakan Metode Heuristic." Pelita Informatika Budi Darma, vol. 4, no. 1, pp. 35-41, 2013.

Dakhi, O. 2013. Belajar Javascript Dengan Mudah Dan Detail. Jakarta: Dapur Buku. pp. 1-202.

Ellis, Rod.(1999). The Study of Second Language Acquisition.

Gass, S. M. and L. Selinker. (2008). Second Language Acquisition. Third Edition. Routledge : New York and London.

James, Carl. (2013). Error in Language Learning and Use. Exploring Error Analysis. Routledge Taylor and Francis Group. London and New York

Millah, Afifatul. (2016). An Error Analysis on the Use of Simple Past Tense in Students' Recount Text Writing. Walisongo State University. Semarang.

Sarumaha, R., Harefa, D., \& Zagoto, Maria M. (2018). Upaya Meningkatkan Kemampuan Pemahaman Konsep Geometri Transformasi Refleksi Siswa Kelas XII-IPA-B SMA Kampus Telukdalam Melalui Model Pembelajaran Discovery Learning Berbantuan Media Kertas Milimeter. Jurnal Education and development, Vol.6 No.1, 90-96. https://doi.org/10.37081/ed.v6i1.668

Shelton, H. James. (1996). Handbook for Technical Writing. Lincolnwood, Illinois USA.

Talib, A. and Tavallaei. (2010). A General Perspective on Role of Theory in Qualitative Research. The Journal of International Social Research.

Turk, C. and J. Kirkman. (1982). Effective Writing. Improving Scientific, technical and Bussines Communication. An Imprint of Routledge London and New York

Zagoto, Maria M. \& Dakhi, O (2018). Pengembangan Perangkat Pembelajaran Matematika Peminatan Berbasis Pendekatan Saintifik Untuk Siswa Kelas XI Sekolah Menengah Atas. Jurnal Review Pendidikan dan Pengajaran, 1(1), 157-170.

Zagoto, Maria M. (2018). Pengembangan Perangkat Pembelajaran Matematika Berbasis Realistic Mathematic Educations Untuk Siswa Kelas V Sekolah Dasar, Jurnal Education And Development, vol. 3, no. 1, p. 53, Feb. 2018. https://doi.org/10.37081/ed.v3i1.139 